\title{
MARKET POWER CONSTRAINED: UNION AND NON-UNION COLLECTIVE BARGAINING OUTCOMES IN THE AUSTRALIA RESOURCES SECTOR
}

\author{
MICHAEL BARRY AND MARCO MICHELOTTI*
}

The Workplace Relations Amendment (Work Choices) Act 2005 is generally regarded as having produced a strong divergence in employment outcomes and opportunities among employment groups and across employment sectors. Whereas poor outcomes are attributed to the lack of bargaining power of disadvantaged and low wage groups, union collective bargaining is seen as having preserved employee entitlements in high wage sectors of the economy. In this paper we examine all forms of collective bargaining in the high-wage resources sector to determine the impact of unionisation on collective bargaining outcomes. To do so, we code and analyse all union collective agreements, employee (non-union) collective agreements, union greenfield agreements, and employer greenfield agreements concluded in the resources sector under the Work Choices legislation. Contrary to expectations, the outcomes of these agreements show strong consistency across a range of substantive and procedural labour standards. These outcomes are attributed to the nature of the product market, employer regulatory objectives, and the adverse effects of Work Choices on union market power.

UNION INVOLVEMENT in bargaining is generally assumed to produce more favourable standards for employees than where unions are absent. In recent years this proposition has been reiterated in relation to disparities in outcomes produced under The Workplace Relations Amendment (Work Choices) Act 2005 (hereafter the Work Choices Act). This logic follows from the generally accepted view among industrial relations scholars that the Work Choices Act reinforced

* Michael Barry is Associate Professor, Department of Employment Relations, Griffith Business School, Griffith University. Marco Michelotti is an Associate Professor at ESC Rennes, France. A copy of the data and computer program syntax files used to conduct the analysis reported in this paper are available from the authors on request. Correspondence to: m.barry@griffith.edu.au 
and supported employer preferences for a more de-collectivised approach to labour management, which was intended to reduce substantive and procedural employment standards (see for example, Knox 2009). Studies examining the impact of the Work Choices Act have therefore focussed on demonstrating that employee wage and conditions standards diminished where employee bargaining power was weakest, and where employees were unable to access union collective agreements (Cowling and Mitchell 2007; Pocock et al 2008).

In this paper we challenge this assumption by examining the contents of all collective agreements stuck in a high-wage sector - the resources sector with and without union involvement during the Work Choices Act era. These agreements included union collective agreements (UCAs), employee (nonunion) collective agreements (ECAs), union greenfield agreements (UGAs) and employer greenfield agreements (EGAs). We code and analyse the content of these agreements to investigate the proposition that union involvement in agreement making is expected to result in superior employment standards for employees. In examining employment standards, we looked at both substantive standards, such as wages and various working conditions, and procedural standards that set limits on an employer's discretion to manage and utilise labour.

In our view, it is significant that these four types of collective agreements encompass a wide disparity of employee and employer bargaining preferences. At a broad level, differences in employer and employee preferences in the resources sectors have been evident in a number of studies, which have shown that unions have fought to retain their presence and influence in the resources sector against concerted employer efforts to limit or remove union involvement from bargaining (for example, see Barry and Waring 2006; Ellem 2003; Hearn McKinnon 2007).

More specifically, bargaining preferences are revealed at one end of our agreement spectrum in the form of UCAs. These agreements are traditional collective agreements made between an individual employer and one or more unions. In the resource sector, these agreements are made with some of the most militant and well organised of all Australian unions, such as the Construction, Forestry, Mining and Energy Union (CFMEU), with the coal industry being the clearest case of this militant approach. EGAs represent the other end of the spectrum. Under the Work Choices Act, employers were capable of striking these agreements without the involvement of any other party and, therefore, they should be taken as explicit employer preferences. Thus, according to conventional industrial relations wisdom, the apparent differences in preferences of the parties in this sector should normally have produced significant divergences in substantive and procedural standards between these distinct collective bargaining instruments.

It is also significant in our view that during the period under review (2006-07), the Australian resources sector was riding an unprecedented mining boom. 
Given the well-established nexus between employment relations outcomes and the prevailing state of the product market in mining (discussed below), this factor was expected to amplify the anticipated differences in outcomes between union agreements and non-union agreements. In other words, unions should ordinarily have been able to extract significant concessions from employers during periods of product market prosperity.

Given these premises, any analysis of the contents of these different types of agreements would only be remarkable if it in fact revealed significant similarities. Such a finding would require a different set of working assumptions about the nature of employment relations in the resources sector and the impact of the Work Choices Act on union bargaining power. This is then the point of departure for our investigation.

Our analysis of collective agreements in the resources sector is structured as follows. The paper begins with an outline of the nature of employment relations in the resources sector, highlighting the nexus between employment relations outcomes and the product market. This discussion is used to motivate one main hypothesis and two sub-hypotheses. The paper then contextualises the study by describing the regulatory preferences of the main industrial relations parties in the lead-up to the introduction of the Work Choices Act. Having outlined our hypotheses and set the context, we describe the numerical method, explain the construction of the database and present the results of our analysis. Finally we seek to provide an explanation of our results and discuss their implications. In particular, we explore the numerical results in light of existing assumptions about union influence in bargaining outcomes in the resources sector in Australia.

\section{Employment Relations in the Resources Sector}

The entire history of employment relations in the resources sector has been characterised by an enduring struggle by workers to improve their terms and conditions of employment through concerted organising, the use of collective bargaining and, where necessary, resort to industrial action. In Australia, as elsewhere, mining collectivism was forged in the context of arduous and dangerous working conditions, and efforts by management to control the production process by institutionalising piecework payments that pitting worker against worker. As Gollan (1963) explained in his history of New South Wales coal mining, unionism arose primarily as a system of worker self-regulation, being designed to limit such competition between miners and to expand available employment.

Despite the advent of technological development and new methods of production over the course of more than a century, these early underground mining traditions endured, and enabled workers to maintain control over the production process until the 1990s. In coal mining, unions' control extended 
to typical areas of managerial prerogative such as recruitment, placement and retrenchment, but it was their ability to determine the pace and volume of production that proved most decisive in securing their overarching industrial relations objectives. Their strategy hinged on using job control and industrial action to extract concessions from employers during various different periods of product market prosperity (see for example Barry and Waring 2006; Beaumont 1975; Smith 1990). In many instances, even the viable threat of industrial action, and the anticipated cost this would have in terms of lost production, induced employers to concede to employee demands and effectively pay for industrial peace (Barry et al 1998).

By contrast, in counter-cyclical periods of product market decline, mining employers have been aggressive, often seeking to claw back worker gains and, where possible, regain control over production. Employer militancy was usually an artefact of the need to address immediate cost of production concerns in the context of falling commodity prices but, on occasions, also arose to challenge the basis of union control over production. For example, in the period 1988-98, coal employers achieved a number of fundamental job control objectives in the context of responding to pressures stemming from weak export coal prices (Barry 1999; Bowden and Russell 1998). Employer-inspired initiatives included the advent of continuous production which signalled the end of the unions' ability to limit production; the introduction of new work models that provided employers with enhanced functional flexibility and reduced job demarcations; and, in the latter part of this period, experimentation with individual employment agreements, increasing their utilisation of contractors, and de-unionising operations (Barry et al 1998; Bowden 2003).

If these were the employer responses to product market decline during the 1990s, the impact of these changes was profound - albeit incomplete - in terms of fulfilling the employers' job control agenda. Thus, Waring and Barry (2001) concluded that between 1995 and 2000, provisions in coal-mining collective agreements that supported union rights and activities became less permissive overall, but were nevertheless retained. Hawke and Robertson (1999) similarly observed that enterprise agreements struck during the latter part of the 1990s revealed employer preferences for reform, but had not substantially changed working time arrangements, nor altered pay systems, nor led to an expansion of multi-skilling, nor undermined seniority as the basis for retrenchment. In their report, Hawke and Robertson (1999: 44) concluded that: 'An analysis of [collective] enterprise agreements on a provision by provision basis failed to reveal any clear trend towards more flexible working arrangements'. These findings indicate that enterprise-level bargaining throughout the 1990s enabled employers to advance their regulatory agenda but that provisions in coal agreements continued to reflect the sector's tradition of worker activism and job control. 
By 2000, product market conditions had once again shifted, this time decisively towards an unprecedented mining boom, which lasted until the second half of 2008. As this upswing took effect, the momentum for individualisation slowed, and the general hard-line employer stance on employment relations began to soften. In fact, some evidence emerged of a renewed employer acceptance of collective bargaining (Barry and Waring 2006: 45). In a sense, pragmatism challenged ideology as some employers reasoned that dealing with unions constructively was favourable to protracted and bitter negotiations in an environment where prosperous market conditions gave unions significant leverage.

After 2000 , unions also had much to gain by making targeted concessions to lock employers into collective agreements. To convince employers of the merits of collective bargaining might reduce the rate of take up of new Australian Workplace Agreements (AWAs). (Indeed, somewhat paradoxically, the spread of AWAs in the iron ore mines of the Pilbara also gave unions a platform to initiate new organising campaigns (Ellem 2003).) In the lead up to the introduction of the Work Choices Act, unions also sought to put collective bargaining agreements in place so as to avoid having to negotiate under a hostile regulatory framework. Some of these agreements, including ones struck in the coal sector, contained new incentives for willing employer partners, such as much more flexible work rosters (Interview, A Vickers, CFMEU).

If employers softened their stance on individualism, these developments showed their enduring commitment to enhanced labour flexibility (see for example, Gunningham 2008: 348). As mentioned, flexibility was secured partly through developments in enterprise bargaining but, importantly, it also came from the spread of contract labour across the sector. The replacement of much of the permanent localised mining communities with 'drive-in, drive-out' and 'flyin, fly-out' contractors (in Queensland and the Pilbara respectively) produced a profound change in mining employment in the late 1990s and after 2000 (Bowden 2003; Di Milia and Bowden 2007; Ellem 2006). As Ellem (2006: 376) explained, the expansion of contract labour and the decline in permanent staff allowed employers in the Pilbara to destabilise community collectivism. In particular, it gave employers the key strategic advantage of reducing their dependence (and therefore corporate risk) on the local mining community situated around the immovable natural mineral resource (see also Jones et al 2007: 59). The other important consequence of the rise of contract labour has been a marked increase in health and safety risk associated with increased travel to and from mine sites (Di Milia and Bowden 2007) and also with the pressures placed on contractors to cut corners and to maintain silence on OHS issues for fear of not meeting (or renewing) contractual obligations (Gunningham 2008).

Taking all of these developments into account, our initial proposition is that the Work Choices Act did not diminish the attractiveness of collective bargaining in 
the resource sector despite the clear intention of the Work Choices Act to promote individualisation. This might have been the case because the introduction of this regulatory framework nullified the prevailing market conditions that favoured employees. The Work Choices Act did this by frustrating the ability of unions to exert market and organisational power in at least three distinct ways. First, the Work Choices Act diminished capacity to organise by severely limiting union rights of entry. Second, it undermined the capacity of unions to take industrial action (and in doing so harm employers by interrupting mining production) by introducing lengthy procedures around secret ballots requirements. Finally, union capacity to use collective bargaining to advance wider interests was limited by the introduction of the notion of 'prohibited content' such as the inclusion in an agreement of any provision that supported trade union training and education. Under this regulatory framework, employers had potentially less to fear from collective agreement making and much to gain in terms of reducing transaction costs associated with multiple (individual) agreement making. The corollary of this proposition is that we would expect to find that union collective bargaining agreements under the Work Choices Act would not produce superior outcomes for unionised workers such as we would normally expect to see during a period of prevailing product market prosperity.

Hence we developed and tested 1 main hypothesis and 2 sub-hypotheses:

Hypothesis 1. Despite the level of sustained product market prosperity, many significant differences in employment conditions will not be found between union collective and non-union collective agreements.

Hypothesis $1(a)$. Despite the level of sustained product market prosperity, many significant differences in substantive standards (e.g. penalty rates), will not be found between union collective and non-union collective agreements.

Hypothesis $I(b)$. Despite the level of sustained product market prosperity, many significant differences in procedural standards that limit the ability of employers to utilise labour, will not be found between union collective and non-union collective agreements.

\section{Method}

The aim of this section is to test the validity of the hypotheses by analysing the union effect on collective agreements under the Work Choices Act in relation to both procedural and substantive labour standards. As mentioned above, under normal circumstances and, despite the introduction of the Work Choices Act, the considerable power unions have traditionally enjoyed in the resource industries, coupled with the level of product market prosperity that prevailed during the operation of this legal framework, should have produced marked differences between union and non-union collective agreements with the former providing 
significantly better entitlements than the latter. In addition, given the superior conditions of employment that coal workers have traditionally enjoyed, we would also expect that union agreements in coal would provide significantly better protections than any other collective agreement.

In order to achieve our primary objective, we use a MANCOVA statistical method to detect significant differences between different types of unions and agreements. MANCOVA is a multivariate statistical instrument which allows for the simultaneous study of multiple dependent variables while controlling for the correlations among them. MANCOVA is generally used to detect statistically significant differences between groups. The size of such differences can then be determined by including variables to control for external influences on the findings. In this way, MANCOVA will enable us to compare differences, in terms of labour standards protection, between the different types of unions and agreements, while simultaneously controlling for the effects of selected control variables, such as establishment size or type of operations, on the overall results.

\section{Profile of Agreements}

The profile of the agreements analysed is shown in Table 1. Of the 112 collective agreements concluded during the operation of the Work Choices Act in the resources sector, the majority were either employee collective $(44 \%)$ or union collective (35\%). Most establishments had more than 20 workers but less than $500 ; 26 \%$ of establishments employed 20 to 99 workers while $45 \%$ had between 100 and 499 employees. Operations were equally divided between coal $(51 \%)$ and non-coal (49\%). Of the 58 union collective and employee greenfield agreements, $39(67 \%)$ had the CFMEU as the only union involved while 11 (19\%) had multiple unions. The AMWU and the AWU alone were involved in $3(5 \%)$ and $5(9 \%)$ agreements respectively. When union activity is analysed in relation to the type of operation, all the 39 agreements that had the CFEMU involved as the sole union were in coal, the AMWU was solely involved in $1(33 \%)$ coal and $2(67 \%)$ non-coal agreements, the AWU had 1 (20\%) agreement concluded alone in coal and $4(80 \%)$ in non-coal operations. In addition, multiple union activities were split between coal (with 4 agreements, $40 \%$ ) and non-coal (with 6 agreements, $60 \%$ ) while $11(20 \%)$ of non-union agreements were in coal and $43(80 \%)$ were in non-coal sectors.

The labour standards that constitute the focus of our investigation were identified by exploring both the Australian and the international literatures. In particular, we used national level measures, developed by Michelotti and Nyland (2006) who, by using an internationally recognised numerical method to compare labour standards across national jurisdictions and over time, indicate that the introduction of the Work Choices Act negatively affected the following aspects of employment protection: penalty rates, overtime, days of leave and 
leave loading, personal leave, redundancy entitlements, capacity of workers to bargain collectively in relation to both numerical and functional flexibility (Michelotti and Nyland 2006). These protections are also identified as being critically undermined by the Work Choices Act by Australian researchers (Fenwick and Landau 2006; Forsyth and Sutherland 2006; Peetz 2006).

\section{Variables}

We named each dependent variable in the following way: severance pay; termination compliance (level of compliance with legal requirements before terminating employment); redundancy consultation (level of consultation with trade unions or employees before redundancy procedures can be initiated); personal leave (days of personal leave); personal leave compliance (level of compliance with legal requirements in relation to personal leave); annual leave (days of annual leave); annual leave compliance (level of compliance with legal requirements in relation to annual leave); overtime (level of retention of previous industry standard); functional flexibility (procedural limitations imposed upon the ability of employers to implement major changes); numerical flexibility (procedural limitations imposed upon the ability of employers to stand down workers) and flexible hours (procedural limitations imposed upon the ability of employers to change workhours).

\section{Sample Procedures}

A database was created by coding the content of all 11 dependent variables for all the enterprise collective agreements $(\mathrm{N}=112)$ concluded in the resource sector from the introduction of the Work Choices Act until December 2007. We used internationally accepted methodologies to quantify provisions in both collective agreements and national legislation (see for example Block and Roberts 2000; Block et al 2003; Cook and Noble 1998; Grubb and Wells 1993; Michelotti and Nyland 2008; OECD 2004). The content of the collective agreements was publicly available through the 'Workplace Authority' database. In line with the classification adopted by the 'Workplace Authority', each collective agreement was classified according to the type of agreement (employee collective agreement, union collective agreement, employer greenfield collective agreement and union greenfield collective agreement), the size of the establishment, the type of operations (i.e. coal or others). We coded coal and non-coal agreements separately because coal mining had traditionally been regulated under a separate industrial relations jurisdiction and because conditions of employment had been higher for coal miners. We also added another independent variable which relates to the type of union involved (for union collective agreements only). 
Table 1: Profile of Agreements

\begin{tabular}{lcc}
\hline Variables & Agreements & $\%$ \\
\hline Type of Agreements $(N=112)$ & 39 & 34.8 \\
Employee Collective & 49 & 43.8 \\
Union Collective & 15 & 13.4 \\
Employer Greenfield & 9 & 8.0 \\
Union Greenfield & & \\
Number of Employees $(N=112)$ & 12 & 10.7 \\
Less than 20 & 29 & 25.9 \\
20 to 99 & 50 & 44.6 \\
100 to 499 & 15 & 13.4 \\
More than 500 & 6 & 5.4 \\
Not disclosed & & \\
Type of Operations $(N=112)$ & 57 & 50.9 \\
Coal & 55 & 49.1 \\
Others & & \\
Type of Union Involved $(N=58)$ & 39 & 67.2 \\
CFMEU & 3 & 5.1 \\
AMWU & 5 & 8.6 \\
AWU & 0 & 0 \\
CEPU & 11 & 18.9 \\
Multiple &
\end{tabular}

\section{Measures}

We developed measures of the level of protection granted to each dependent variable with higher scores indicating higher levels of labour standards protection. The 11 standards were grouped in the following way:

1. Substantive standards: severance pay, termination of employment, days of personal leave and level of compliance with legal requirements, days of annual leave and level of compliance with legal requirements; level of retention of previous industry standard in relation to overtime.

2. Procedural standards: level of consultation with unions or employees before redundancy procedures are initiated; procedural limitations imposed upon the ability of employers to implement major changes; procedural limitations imposed upon the ability of employers to stand down workers; procedural limitations imposed upon the ability of employers to change workhours.

Typically, a substantive standard scored higher the higher the entitlement granted by the agreement. For example, the standard Severance pay was coded 1 if there was no provision in the agreement that specified the amount of severance pay required, 2 if the level of pay was below industry standard (with reference to either relevant state legislation or past awards), 3 if it complied with the industry 
standard and four if it was above. Three substantive standards also relate to the level of compliance with federal legislation; they are termination compliance, personal leave compliance and annual leave compliance. These variables were coded 1 if the provision in the collective agreement complied with the minimum legal requirements and 2 if such provision was above. In addition, two standards, personal leave and annual leave, reported the actual days of leave or weeks of leave granted by the agreement. We used the following basic industry award conditions as benchmarks to code substantive provisions in collective agreements. Severance pay: one week of pay for each year of continuous service; notice of termination: proportional to seniority up to a statutory maximum of 4 weeks for workers who have been employed for more than 5 years; personal leave: traditionally 10 days but considerably higher in coal due to OHS and workers' compensation concerns; annual leave: 4 weeks after a year of continuous service plus a leave loading of $17.5 \%$ (workers in coal mines have traditionally enjoyed 5 weeks); overtime: time and a half for the first three hours and double time thereafter; penalty rates for work performed on public holidays or on Sunday: double time.

Procedural standards scored higher the more stringent the requirements to involve unions and employees in the management of both functional and numerical flexibility. For example, redundancy consultation was coded 1 if the collective agreement did not envisage any consultative procedure, 2 if the process was only symbolic (meaning that management retains the final decision), 3 if there was a formal process with the possibility to have access to an 'external' umpire in case the dispute remained unresolved, and 4 if there was a formal process and employees were also paid seniority allowances in addition to contractual severance pay.

\section{Results}

As previously mentioned, two one-way between-groups multivariate analyses of covariance (MANCOVA) were performed. In the first analysis the independent variable was the type of union (CFMEU, AMWU, AWU, multiple and no union) while the dependent variables consisted of scores for each of the 11 labour standards listed. Number of employees and type of operations were used as covariates. We were able, in this way, to take into account the effects of both establishment size and type of operation on the final results. Table 2 shows means and standard deviation for each dependent variable.

A statistically significant difference between union type on the combined dependent variables was detected $\mathrm{F}(44,361)=3.07, \mathrm{p}<0.05$, Wilks Lambda $=0.30$. Specifically, significant differences between the different type of unions (including non-unions agreements) were found for the following dependent variables: severance pay $F(4,104)=5.20, p<0.05$; level of compliance with legislation in relation to termination of employment $\mathrm{F}(4,104)=2.65, \mathrm{p}<0.05$; 
annual leave $F(4,104)=3.80, p<0.05$; level of compliance with legislation in relation to annual leave $\mathrm{F}(4,104)=4.58, \mathrm{p}<0.05$; Overtime $\mathrm{F}(4,104)=4.40$, $p<0.05$ and the ability of employers to change workhours $F(4,104)=6.42$, $\mathrm{p}<0.05$. Interestingly, there was not a significant difference between union and non-union agreements on two critical procedural standards: procedural limitations imposed upon the ability of employers to implement major changes and procedural limitations imposed upon the ability of employers to stand down workers.

As valuable as this information is, we needed further tests to clarify the nature of such differences and to identify the instances in which union collective agreements provided better conditions than non-union collective agreements. Thus, pairwise comparison tests revealed that the CFMEU or agreements involving more than one union tended to have higher scores than no unions in most significant instances (but by no means all). Severance pay was more likely to be higher if the CFMEU or multiple unions were involved rather than no union. The level of compliance of agreements in relation to termination tended to be higher if multiple unions were involved rather than the CFMEU alone. The number of weeks of annual leave was more likely to be higher if multiple unions were involved but only in comparison with agreements in which the AWU alone was involved, or non-union agreements. The level of compliance with legislation in relation to annual leave was more likely to be higher if the AMWU or multiple unions or no unions were involved rather than the CFMEU alone. Overtime rates were more likely to be retained if the CFMEU was involved than if no union was present. Finally, the ability of employers to change workhours was more likely to be limited if the CFMEU, the AWU, or multiple unions were involved than if no unions were present. In short, this first analysis revealed an uneven scenario where a union effect was difficult to detect.

The second MANCOVA was performed to detect statistically significant differences in employment standards contained in agreements based on type of union and type of sector (coal and non-coal). This procedure was required to detect any possible interaction between the union and sector effects on the dependent variables and single out which union (if any) had the most profound effect in coal and non-coal operations. This was necessary because, as mentioned in the previous section, unions in coal in general, and the CFMEU in particular, have traditionally been able to extract considerably more favourable employment conditions in coal operations than those established in non-union agreements particularly in non-coal sectors. The independent variables in this case were the type of union (CFMEU, AMWU/AWU, multiple and no union) and the type of sector (coal and non-coal) while the dependent variables still consisted of scores for each of the 11 labour standards listed. The number of employees was used as covariates. As with the first analysis, using number of employees as a control variable enabled us to take into consideration the effect of the size of the 
Table 2: Labour Standards Protection by Type of Union

\begin{tabular}{|c|c|c|c|c|c|c|}
\hline Variable & $\begin{array}{c}C F M E U \\
\mathrm{M}(\mathrm{SD}) \mathrm{N}=39\end{array}$ & $\begin{array}{c}A M W U \\
\mathrm{M}(\mathrm{SD}) \mathrm{N}=3\end{array}$ & $\begin{array}{c}A W U \\
\mathrm{M}(\mathrm{SD}) \mathrm{N}=5\end{array}$ & $\begin{array}{c}\text { Multiple } \\
\mathrm{M}(\mathrm{SD}) \mathrm{N}=11\end{array}$ & $\begin{array}{c}\text { Non-union } \\
\mathrm{M}(\mathrm{SD}) \mathrm{N}=54\end{array}$ & $\begin{array}{c}\text { Total } \\
\mathrm{M}(\mathrm{SD}) \mathrm{N}=112\end{array}$ \\
\hline Severance pay & $3.51(0.76)$ & $2.33(1.53)$ & $2.80(1.30)$ & $3.40(0.70)$ & $2.22(0.98)$ & $2.81(1.09)$ \\
\hline Termination compliance & $1.03(0.16)$ & $1.00(0.00)$ & $1.00(0.00)$ & $1.20(0.42)$ & $1.02(0.14)$ & $1.04(0.19)$ \\
\hline Redundancy consultation & $1.92(0.98)$ & $1.00(0.00)$ & $2.00(0.71)$ & $1.90(0.74)$ & $1.44(0.66)$ & $1.67(0.82)$ \\
\hline Personal leave & $15.564(2.10)$ & $9.33(1.15)$ & $10.00(0.00)$ & $11.50(2.41)$ & $17.00(25.28)$ & $15.48(17.75)$ \\
\hline Personal leave compliance & $2.59(0.50)$ & $1.67(0.58)$ & $2.00(0.00)$ & $2.30(0.48)$ & $2.22(0.42)$ & $2.33(0.49)$ \\
\hline Annual leave & $4.87(0.41)$ & $4.00(0.00)$ & $4.00(0.00)$ & $4.90(0.99)$ & $4.28(0.45)$ & $4.52(0.58)$ \\
\hline Annual leave compliance & $1.36(0.49)$ & $2.00(0.00)$ & $1.40(0.55)$ & $1.70(0.48)$ & $1.61(0.49)$ & $1.53(0.50)$ \\
\hline Overtime & $2.36(0.63)$ & $2.33(0.58)$ & $2.00(0.00)$ & $2.10(0.88)$ & $1.63(0.56)$ & $1.96(0.69)$ \\
\hline Functional flexibility & $1.92(1.11)$ & $2.33(1.15)$ & $2.80(1.09)$ & $1.80(1.13)$ & $2.26(0.91)$ & $2.13(1.02)$ \\
\hline Numerical flexibility & $2.00(0.61)$ & $1.67(0.58)$ & $1.00(0.00)$ & $1.70(0.48)$ & $1.41(0.66)$ & $1.63(0.67)$ \\
\hline Flexible hours & $4.21(1.43)$ & $3.67(1.15)$ & $4.40(2.30)$ & $4.10(1.73)$ & $2.70(0.90)$ & $3.46(1.46)$ \\
\hline
\end{tabular}


establishment on the dependent variables. It is important to note that in order to perform this analysis, it was necessary to merge AMWU and AWU agreements in one category to reach a statistically reliable sample size. Table 3 shows means and standard deviations for each dependent variable in coal and non-coal operations. The combined effect of both type of unions and type of operation is defined, in statistical terms, as an interaction effect because it enables the analyst to assess the combined effect of two independent variables when the effect of one of the variables differs depending on the level of the other variable.

An interaction effect and statistically significant difference between union type and sector on the combined variables was detected $F(22,186)=2.41$, $\mathrm{p}<0.05$, Wilks Lambda $=0.61$. Statistically significant differences, for each dependent variable, were found for the following variables: severance pay $\mathrm{F}(2,103)=8.28, \mathrm{p}<0.05$; annual leave $\mathrm{F}(2,103)=6.22, \mathrm{p}<0.05$; limitations on the ability of employers to implement major changes $\mathrm{F}(2,103)=4.46, \mathrm{p}<0.05$; and the ability of employers to change workhours $\mathrm{F}(2,103)=3.78, \mathrm{p}<0.05$.

Following this significant interaction, simple main effects were run to examine the exact nature of the interaction in the coal and non-coal sectors. A simple main effect is the effect of one independent variable within one level of a second independent variable. In the coal sector, the following interactions were observed: in relation to severance pay, collective agreements in which the AMWU or the AWU were involved had lower standards than if other or multiple unions were involved or, interestingly, than non-union agreements. In relation to annual leave, the CFEMU had a positive effect when compared to agreements where the AMWU/AWU was involved but not when compared with non-union agreements. In fact, non-union agreements provide for more generous entitlements than if the AMWU or the AWU were involved. The last significant interaction detected in coal collective agreements relates to the ability of employers to change workhours. In this case the involvement of the CFMEU bears positive outcomes for employees but only when compared with non-union agreements.

In non-coal agreements, the following statistically significant interactions were detected: in relation to severance pay, the AMWU, the AWU or multiple unions had a positive affect when compared to non-union agreements. The second significant interaction was related to functional flexibility as the involvement of the AMWU or the AWU meant that the employers' ability to implement major changes was more constrained than if multiple unions were involved. Importantly in this instance, collective agreements where the AMWU/AWU were involved did not offer better protection than non-union agreements. Finally, collective agreements where the AMWU the AWU or multiple unions were involved had protections that constrained the ability of employers to change workhours to a greater degree than non-union agreements.

These results are significant in a number of ways and, in many respects, 
support our hypotheses. With regard to hypothesis 1 , while we found some differences between union collective and non-union collective agreements, such differences were often marginal, or the nature of the interaction quite surprising. For example it is very significant that non-union collective agreements in the coal sector provided the same level of entitlements with regard to severance pay and days of annual leave as that offered by agreements in which the CFMEU alone was involved which in turn provide better conditions than if only the AMWU/AWU was involved. It is also significant that we did not find any difference between union collective agreements and non-union collective agreements in relation to two fundamental procedural standards we measured, i.e. procedural limitations imposed upon the ability of employers to implement major changes and procedural limitations imposed upon the ability of employers to stand down workers. These are important procedural standards that would normally constrain employers in enhancing labour flexibility and extending control over the production process. This is not to suggest that a union effect cannot be detected at all but rather that such an effect is marginal or limited to a few specific areas of employment standards protection.

A similar line of argument can also be run for sub-hypotheses 1(a) and 1(b). For example, when sub-hypothesis 1 (a) is considered, it is very interesting to note that non-union collective agreements offer very similar substantive conditions when compared to union collective agreements. The effect is particularly evident in the coal sector where, as previously noted, non-union agreements provide for the same or better levels of entitlements than union collective agreements in relation to severance pay and annual leave. This result is unexpected for, as mentioned, we would normally expect a much stronger union effect in relation to substantive standards in coal mining. It is also interesting to note that in relation to non-coal agreements, a moderate union effect could be detected only in relation to severance pay. This finding too is rather unexpected given what was observed in coal collective agreements.

Perhaps, the most remarkable results relate to the testing of sub-hypothesis 1(b) and the extent to which it was possible to detect significant differences in procedural standards between union and non-union collective agreements. At a general level, sub-hypothesis 1(b) is supported as we did not detect any significant difference between union and non-union collective agreements in relation to two key standards that relate respectively to the ability of employers to implement major changes, and procedural limitations imposed upon the capacity of management to stand down workers. The only exception could be found in relation to limitations imposed upon the ability of employers to change workhours where we were able to identify a union effect in both coal and noncoal collective agreements. 
Table 3: Labour Standards Protection by Type of Union and Type of Sector

\begin{tabular}{|c|c|c|c|c|c|c|c|c|c|c|c|c|}
\hline \multirow[b]{2}{*}{ Variable } & \multicolumn{3}{|c|}{$\begin{array}{c}\text { CFMEU } \\
\mathrm{M}(\mathrm{SD}) \mathrm{N}=39\end{array}$} & \multicolumn{3}{|c|}{$\begin{array}{l}\text { AMWU/AWU } \\
\mathrm{M}(\mathrm{SD}) \mathrm{N}=8\end{array}$} & \multicolumn{3}{|c|}{$\begin{array}{c}\text { Multiple } \\
\text { M (SD) } N=11\end{array}$} & \multicolumn{3}{|c|}{$\begin{array}{c}\text { Non-Union } \\
\mathrm{M}(\mathrm{SD}) \mathrm{N}=54 \\
\end{array}$} \\
\hline & Coal & $n /$ coal & Total & Coal & $n /$ coal & Total & Coal & $n / c o a l$ & Total & Coal & $n /$ coal & Total \\
\hline Severance pay & $\begin{array}{c}3.51 \\
(0.76)\end{array}$ & - & $\begin{array}{c}3.51 \\
(0.76)\end{array}$ & $\begin{array}{c}1.00 \\
(0.00)\end{array}$ & $\begin{array}{c}3.17 \\
(0.98)\end{array}$ & $\begin{array}{c}2.62 \\
(1.30)\end{array}$ & $\begin{array}{c}3.25 \\
(0.96)\end{array}$ & $\begin{array}{c}3.50 \\
(0.55)\end{array}$ & $\begin{array}{c}3.40 \\
(0.70)\end{array}$ & $\begin{array}{c}2.91 \\
(1.30)\end{array}$ & $\begin{array}{c}2.05 \\
(0.81)\end{array}$ & $\begin{array}{c}2.22 \\
(0.98)\end{array}$ \\
\hline Termination compliance & $\begin{array}{c}1.03 \\
(0.16)\end{array}$ & - & $\begin{array}{c}1.03 \\
(0.16)\end{array}$ & $\begin{array}{c}1.00 \\
(0.00)\end{array}$ & $\begin{array}{c}1.00 \\
(0.00)\end{array}$ & $\begin{array}{c}1.00 \\
(0.00)\end{array}$ & $\begin{array}{l}1.25 \\
(0.50)\end{array}$ & $\begin{array}{c}1.17 \\
(0.41)\end{array}$ & $\begin{array}{c}1.20 \\
(0.42)\end{array}$ & $\begin{array}{c}1.09 \\
(0.30)\end{array}$ & $\begin{array}{c}1.00 \\
(0.00)\end{array}$ & $\begin{array}{c}1.02 \\
(0.14)\end{array}$ \\
\hline Redundancy consultation & $\begin{array}{c}1.92 \\
(0.98)\end{array}$ & - & $\begin{array}{c}1.92 \\
(0.98)\end{array}$ & $\begin{array}{c}1.00 \\
(0.00)\end{array}$ & $\begin{array}{c}1.83 \\
(0.75)\end{array}$ & $\begin{array}{c}1.62 \\
(0.74)\end{array}$ & $\begin{array}{c}2.00 \\
(0.00)\end{array}$ & $\begin{array}{c}1.83 \\
(0.98)\end{array}$ & $\begin{array}{c}1.90 \\
(0.74)\end{array}$ & $\begin{array}{c}1.27 \\
(0.47)\end{array}$ & $\begin{array}{c}1.49 \\
(0.70)\end{array}$ & $\begin{array}{c}1.44 \\
(0.66)\end{array}$ \\
\hline Personal leave & $\begin{array}{l}15.564 \\
(2.00)\end{array}$ & - & $\begin{array}{l}15.56 \\
(2.00)\end{array}$ & $\begin{array}{c}9.00 \\
(1.41)\end{array}$ & $\begin{array}{l}10.00 \\
(0.00)\end{array}$ & $\begin{array}{c}9.75 \\
(0.71)\end{array}$ & $\begin{array}{l}12.50 \\
(2.89)\end{array}$ & $\begin{array}{l}10.83 \\
(2.04)\end{array}$ & $\begin{array}{l}11.50 \\
(2.41)\end{array}$ & $\begin{array}{c}33.12 \\
(42.97)\end{array}$ & $\begin{array}{c}12.86 \\
(16.77)\end{array}$ & $\begin{array}{c}17.00 \\
(25.29)\end{array}$ \\
\hline Personal leave compliance & $\begin{array}{c}2.59 \\
(0.50)\end{array}$ & - & $\begin{array}{c}2.59 \\
(0.50)\end{array}$ & $\begin{array}{c}1.50 \\
(0.71)\end{array}$ & $\begin{array}{c}2.00 \\
(0.00)\end{array}$ & $\begin{array}{c}1.88 \\
(0.35)\end{array}$ & $\begin{array}{c}2.50 \\
(0.58)\end{array}$ & $\begin{array}{c}2.17 \\
(0.41)\end{array}$ & $\begin{array}{c}2.30 \\
(0.48)\end{array}$ & $\begin{array}{c}2.73 \\
(0.47)\end{array}$ & $\begin{array}{c}2.09 \\
(0.29)\end{array}$ & $\begin{array}{c}2.22 \\
(0.42)\end{array}$ \\
\hline Annual leave & $\begin{array}{c}4.87 \\
(0.41)\end{array}$ & - & $\begin{array}{c}4.87 \\
(0.41)\end{array}$ & $\begin{array}{c}4.00 \\
(0.00)\end{array}$ & $\begin{array}{c}4.00 \\
(0.00)\end{array}$ & $\begin{array}{c}4.00 \\
(0.00)\end{array}$ & $\begin{array}{l}4.75 \\
(0.50)\end{array}$ & $\begin{array}{c}5.00 \\
(1.26)\end{array}$ & $\begin{array}{c}4.90 \\
(0.99)\end{array}$ & $\begin{array}{c}4.90 \\
(0.30)\end{array}$ & $\begin{array}{c}4.12 \\
(0.32)\end{array}$ & $\begin{array}{c}4.28 \\
(0.45)\end{array}$ \\
\hline Annual leave compliance & $\begin{array}{c}1.36 \\
(0.49)\end{array}$ & - & $\begin{array}{c}1.36 \\
(0.49)\end{array}$ & $\begin{array}{c}2.00 \\
(0.00)\end{array}$ & $\begin{array}{c}1.50 \\
(0.55)\end{array}$ & $\begin{array}{c}1.62 \\
(0.52)\end{array}$ & $\begin{array}{c}1.75 \\
(0.50)\end{array}$ & $\begin{array}{c}1.67 \\
(0.52)\end{array}$ & $\begin{array}{c}1.70 \\
(0.48)\end{array}$ & $\begin{array}{c}1.91 \\
(0.30)\end{array}$ & $\begin{array}{c}1.53 \\
(0.50)\end{array}$ & $\begin{array}{c}1.61 \\
(0.49)\end{array}$ \\
\hline Overtime & $\begin{array}{c}2.36 \\
(0.63)\end{array}$ & - & $\begin{array}{c}2.36 \\
(0.63)\end{array}$ & $\begin{array}{c}2.00 \\
(0.00)\end{array}$ & $\begin{array}{c}2.17 \\
(0.41)\end{array}$ & $\begin{array}{c}2.10 \\
(0.88)\end{array}$ & $\begin{array}{c}2.25 \\
(0.96)\end{array}$ & $\begin{array}{c}2.00 \\
(0.89)\end{array}$ & $\begin{array}{c}2.10 \\
(0.88)\end{array}$ & $\begin{array}{c}1.64 \\
(0.67)\end{array}$ & $\begin{array}{c}1.63 \\
(0.54)\end{array}$ & $\begin{array}{c}1.63 \\
(0.56)\end{array}$ \\
\hline Functional flexibility & $\begin{array}{c}1.92 \\
(1.11)\end{array}$ & - & $\begin{array}{c}1.92 \\
(1.11)\end{array}$ & $\begin{array}{c}1.00 \\
(0.00)\end{array}$ & $\begin{array}{c}3.17 \\
(0.41)\end{array}$ & $\begin{array}{c}2.62 \\
(1.06)\end{array}$ & $\begin{array}{c}2.25 \\
(0.96)\end{array}$ & $\begin{array}{c}1.50 \\
(1.22)\end{array}$ & $\begin{array}{c}1.80 \\
(1.13)\end{array}$ & $\begin{array}{c}2.09 \\
(0.54)\end{array}$ & $\begin{array}{c}2.30 \\
(0.99)\end{array}$ & $\begin{array}{c}2.26 \\
(0.91)\end{array}$ \\
\hline Numerical flexibility & $\begin{array}{c}2.00 \\
(0.61)\end{array}$ & - & $\begin{array}{c}2.00 \\
(0.61)\end{array}$ & $\begin{array}{c}1.00 \\
(0.00)\end{array}$ & $\begin{array}{c}1.33 \\
(0.52)\end{array}$ & $\begin{array}{c}1.25 \\
(0.46)\end{array}$ & $\begin{array}{c}1.75 \\
(0.50)\end{array}$ & $\begin{array}{c}1.67 \\
(0.52)\end{array}$ & $\begin{array}{c}1.70 \\
(0.48)\end{array}$ & $\begin{array}{c}1.91 \\
(0.94)\end{array}$ & $\begin{array}{c}1.28 \\
(0.50)\end{array}$ & $\begin{array}{c}1.41 \\
(0.66)\end{array}$ \\
\hline Flexible hours & $\begin{array}{c}4.21 \\
(1.44)\end{array}$ & - & $\begin{array}{c}4.21 \\
(1.44)\end{array}$ & $\begin{array}{c}2.00 \\
(1.41)\end{array}$ & $\begin{array}{c}4.83 \\
(1.47)\end{array}$ & $\begin{array}{c}4.12 \\
(1.89)\end{array}$ & $\begin{array}{c}4.25 \\
(2.06)\end{array}$ & $\begin{array}{c}4.00 \\
(1.67)\end{array}$ & $\begin{array}{c}4.10 \\
(1.73)\end{array}$ & $\begin{array}{c}2.91 \\
(0.83)\end{array}$ & $\begin{array}{c}2.65 \\
(0.92)\end{array}$ & $\begin{array}{c}2.70 \\
(0.90)\end{array}$ \\
\hline
\end{tabular}




\section{The Work Choices Act and Collective Bargaining in the Resource Sector: A Zero Sum Game?}

The data analysis shows that, under the Work Choices Act, the capacity for unions in the resources sector to make gains through collective bargaining was limited. The first analysis indicates that while unions had a positive impact on some substantive standards, managerial prerogative was consolidated irrespective of the type of union involved. This result is in line with the trend that was described earlier as the conditions of the product market have allowed employers to continue to pay wages that were well above market clearing levels (efficiency wages) while employer regulatory protections introduced by the Work Choices Act seem to have prevented unions from using their market power to retain or regain control over the production process. It should be noted that given the lack of longitudinal data, however, we cannot establish with absolute certainty a nexus of causality between the introduction of the Work Choices Act and the pattern described above.

The second, and more disaggregate, analysis portrays an even darker picture for unions as it clearly shows that in some instances non-union agreements provided better employment conditions than union agreements. This is a particularly interesting finding in terms of what might be speculated about individual contracts given the well-established content similarity between nonunion collective agreements and individual contracts (Mitchell et al 2005; Peetz 2006). For example, in coal operations, and in relation to severance pay and annual leave, non-union agreements provided significantly better entitlements than if the AMWU or the AWU were involved. Importantly, in these two areas, even a traditionally strong union like the CFMEU was unable to extract better employment conditions than if no union was involved. In non-coal operations, unions (AMWU/AWU or multiple unions) made a difference only with regard to severance pay and the ability of employers to change workhours. Importantly, in sectors other than coal, the presence of unions did not seem to limit the freedom of employers to implement major changes in any relevant way.

These findings have the potential to shed more light on the impact of the Work Choices Act on the outcomes of agreement making and to changes in union power. Interestingly, the first analysis does not fully support the assumption that the introduction of new bargaining instruments under the Work Choices Act (such as employer greenfield agreements) would lead to divergent outcomes, with union collective bargaining offering superior terms and conditions for employees. In particular, substantive standards were found to be consistently high across all four types of collective agreements. This finding adds complexity to the proposition that superior employment conditions reflect the bargaining capacity of workers, which is greater when they continue to be supported by union collective bargaining. Contrary to that view, the evidence presented here 
supports the proposition that substantive conditions in all collective agreements were high because employers had the capacity and willingness to pay, irrespective of the type of agreement and the level of union involvement.

Given the state of the product market during the Work Choices Act era, it is also reasonable to argue that substantive standards remained high across the board because employers appeared less concerned about substantive wages and conditions of employment than about securing extensive gains in managerial prerogative by weakening procedural labour standards. That firms were able to enjoy wide discretion in functional, numerical and temporal flexibility across all types of agreements again highlights the difficulties unions faced under the Work Choices Act in exerting market power thought collective agreement making. In the mining sector, union capacity to shape terms and conditions of employment has always reflected, in no small measure, their ability to represent a credible threat to the ability of employers to maintain or increase production. The capacity of unions to raise such a credible threat was certainly hindered by events occurring prior to the Work Choices Act (as mentioned above) such as the influx of contractors into the permanent mining workforce, and employer efforts to individualise and de-unionise during the late 1990s. However, union capacity to threaten managerial control over production was fatally wounded by provisions introduced in the Work Choices Act that made union activities 'prohibited content', limited union capacity to organise at the workplace, and that mandated difficult and cumbersome procedures for industrial action, including secret ballots.

It was the latter of these provisions that severely limited unions' ability to exert market power. Thus, we contend that it was the impact of the Work Choices Act itself, rather than the bargaining instruments created by this regulatory framework, that is critical to understanding the difficulties mining unions faced in securing superior bargaining outcomes, and vital to understanding employer preferences in bargaining instruments. Taking this point further, we would argue that the Work Choices Act allowed employers to be agnostic about bargaining instruments whereas they had previously been fervent in their support for individualisation as a means to reduce union market power. One of the unintended consequences of the Work Choices Act for the resources sector was, therefore, that it allowed employers to secure job control through collective bargaining. In simple terms, union collective bargaining under the Work Choices Act represented less of a threat to employer interests than it had at any period prior to its introduction.

Standardisation of wages and conditions across these collective agreements was therefore not evidence of a 'union threat' effect. Rather, we assert that employer opposition to union collective bargaining decreased because the power of unions to create a 'wages gap' between union and non-union collective agreements was reduced, as the data clearly demonstrate. 


\section{Conclusion}

This paper has provided an analysis of all types of collective agreements made in the Australian resources sector during the Work Choices Act era, from 2006 to 2007 . The main finding of this paper is that collective bargaining outcomes surprisingly revealed marked similarity in both substantive and procedural labour standards across all types of collective agreements. While all types of agreements retained high employee entitlements in terms of substantive conditions, procedural labour standards that might have limited employer discretion in labour utilisation were weak across all types of agreements.

Given that market conditions in the resources sector were highly favourable for collective bargaining to produce a union wage effect, what the data show was that the Work Choices Act helped employers to neutralise the market in favour of employers. Therefore, our findings refute the popular view of the Work Choices Act as a neo-liberal instrument of marketisation. Rather, we assert that the heavy-handed prescriptions contained in this regulatory framework prevented free collective bargaining from occurring, and this was exactly the type of protection employers were seeking to prevent union 'rent seeking behaviour' as employers used collective bargaining to extend labour flexibility so as to make inroads into areas of union job control.

These findings have important implications for current policy debates. Given the strong relationship between prevailing product market conditions and bargaining outcomes in the Australian resources industry, the similarities in terms and conditions observed across different types of collective agreements, and the fact that union collectives failed to restrain employer control over the production process, reveals the level to which union market and organisational power remained constrained during the time Work Choices operated. With the abolition of AWAs, and a renewed push for collective bargaining proposed by the new federal Labor government, the results of this study suggest that unions require more than a minimal set of regulatory protections to support collective bargaining if they are to succeed in delivering the types of outcomes that will provide incentives for new members to join or existing members to remain unionists. Indeed, the findings demonstrate that employers might be quite prepared to use collective agreements if the procedural rules around bargaining support their regulatory preferences by restraining unions from exerting market power.

\section{References}

Barry, M (1999) 'Employer Associations in Coal Mining,' in P Sheldon and L Thornthwaite, eds, Catalysts and Captives: Employer Associations and Industrial Relations Change in Australia. Sydney: Allen \& Unwin, 115-37.

Barry, M, Bowden, B and Brosnan, P (1998) The Fallacy of Flexibility: Workplace Change in the Queensland Open-Cut Coal Industry: Sydney: Allen \& Unwin. 
Barry, M and Waring, P (2006) 'Black Coal Mining,' in P Waring and M Bray, eds, Evolving Employment Relations: Industry Studies from Australia. Sydney: McGraw-Hill, pp. 37-51.

Beaumont, P (1975) 'Conflict in Coal: The NSW Experience.' Journal of Industrial Relations, 17 (1) 44-59.

Block, R and Roberts, K (2000) 'A Comparison of Labour Standards in the United States and Canada.' Relations Industrielles, 55(2) 273-307.

Block, R, Roberts, K and Clarke, R (2003) Labour standards in the United States and Canada Kalamazoo. Michigan: W.E. Upjohn Institute for Employment Research.

Bowden, B (2003) 'Regulating Outsourcing: The use of Contractors on the Central Queensland Coalfields, 1974-2003.' Labour \& Industry, 14(1) $41-57$.

Bowden, B and R Russell (1998) 'Benchmarking, Global Best Practice and Production Re-Norming in the Australian Coal Industry: The Impact of Globalization.' Paper presented at the International Conference on Globalization and its Discontents, Vancouver, July.

Cooke, W and Noble, D (1998) 'Industrial Relations Systems and US Foreign Direct Investment Abroad.' British Journal of Industrial Relations, 34(4) 581-609.

Cowling, S and Mitchell, R. (2008) 'Taking the Low Road: Mining Wage Determination under WorkChoices.' Journal of Industrial Relations, 49(5) 741-56.

Di Milia, L and Bowden, B (2007) 'Unanticipated Safety Outcomes: Shiftwork and Drive-In, Drive-Out Workforces in Queensland's Bowen Basin.' Asia Pacific Journal of Human Resources, 45(1): 100-12.

Ellem, B (2003) 'New Unionism in the Old Economy: Community and Collectivism in the Pilbara's Mining Towns.' Journal of Industrial Relations, 45(4): 423-41.

Ellem, B (2006) 'Scaling Labour: Australian Unions and Global Mining.' Work, Employment and Society, 20(2): 369-87.

Fenwick, C and Landau, I (2006) 'WorkChoices in International Perspective.' Australian Journal of Labour Law, 19(2): 127-43.

Forsyth, A and Sutherland, C (2006) 'Collective Labour Relations Under Siege: The WorkChoices Legislation and Collective Bargaining.' Australian Journal of Labour Law, 19(2): 183-97.

Gollan, R (1963) The Coalminers of New South Wales: A History of the Union, 1860-1960. Melbourne: Melbourne University Press.

Grubb, D and Wells, W (1993) 'Employment Regulation and Patterns of Work in EC Countries.' OECD Economic Studies, 21 (Winter): 7-58.

Gunningham, N (2008) 'Occupational Health and Safety, Worker Participation and the Mining Industry in a Changing World of Work.' Economic and Industrial Democracy, 29 (3): 336-61.

Hawke, A and Robertson, F (1999) 'Enterprise Bargaining in the Coal Industry.' National Institute of Labour Studies, Monograph Series Number 5, Adelaide.

Hearn MacKinnon, B (2007) Behind WorkChoices: How One Company Changed Australia's Industrial Relations. Melbourne: Heidelberg Press.

Jones, M, Marshall, S and Mitchell, R (2007) 'Corporates Social Responsibility and the Management of Labour in Two Australian Mining Companies.' Corporate Governance: An International Review, 57-67.

Knox, A (2009) 'Better the Devil you know? An Analysis of Employers' Bargaining Preferences in the Australian Hotel Industry.' Journal of Industrial Relations, 51(1): $25-44$. 
Michelotti, M and Nyland C (2006) 'Measuring Regulatory Changes in Employment Protection Labour Standards in Australia, 1979 to 2000.' International Journal of Comparative Labour Law and Industrial Relations, 22(1): 39-80.

Michelotti, M and Nyland C (2008) 'Do Market Economies Allow Diversity in Labour Standards Regulation? The Case of Italy 1979-2003.' European Journal of Industrial Relations, 14(2): 177-95.

Mitchell, R, Campbell, R, Barnes, A, Bicknell, E, Creighton, K, Fetter, J and Korman, S (2005) 'What's Going on with the No Disadvantage Test? An Analysis of Outcomes and Processes under the Workplace Relations Act 1996 (Cwlth).' Journal of Industrial Relations, 47(4): 393-423.

Organization for Economic Cooperation and Development (OECD) (2004) Employment Outlook. Paris: OECD.

Peetz, D (2006) Brave New Workplace. Sydney: Allen \& Unwin.

Pocock, B, Elton, J, Preston, A, Charlesworth, S, MacDonald, F, Baird, M, Cooper, R and Ellem, B (2008) 'The Impact of "WorkChoices" on Women in Low Paid Employment in Australia: A Quantitative Analysis.' Journal of Industrial Relations, 50(3): 475-88.

Smith, G (1990) 'Union-Employer Bargaining and Product Market Developments: The Black Coal Industry.' Journal of Industrial Relations, 32(1): 19-31.

Waring, P and Barry, M (2001) 'The Changing Frontier of Control in Coal: Evidence from a Decade of Enterprise Bargaining in the Australian Black Coal Mining Industry.' Australian Bulletin of Labour, 27(3): 216-37. 